\title{
Linguistic and Rhetorical Subjectivity in Media Discourse
}

\author{
Umar Bello $^{1}$ \\ ${ }^{1}$ English Language Center, Jubail Industrial College, Jubail, Saudi Arabia \\ Correspondence: Umar Bello, English Language Center, Jubail Industrial College, Jubail 31961, P. O. BOX 10099, \\ Saudi Arabia. E-mail: bello.umar@gmail.com
}

Received: October 29, 2013 Accepted: December 13, 2013 Online Published: January 23, 2014

doi:10.5539/ijel.v4n1p70 URL: http://dx.doi.org/10.5539/ijel.v4n1p70

\begin{abstract}
s
This research paper tries to use Critical Discourse Analysis especially Van Dijk's (1988) Discourse Analytical Perspective and complementary insights from Fairclough $(1988,1995)$ and Van Leeuwen (2008) to analyze two news reports from a Nigerian newspaper. These reports from the Daily Sun show two distinct and parallel kinds of reportage even though they both have a particular overriding theme which is violence. This paper analyzes both the textual and contextual aspects of the reports. The result reveals that news reports are sometimes made from an $a$ priori perspective based on frames recalled and rebuilt in fresher news and that actors and actions are constructed to suit the perspectives. In this analysis, we see how Muslims in the Jos attacks are built into frames where they can only be assailants not victims even in a case where they are grossly victimized. This paper enforces the notion of bias and subjective reportage of events in the media as espoused by CDA.
\end{abstract}

Keywords: critical discourse analysis, macrostructures, jos, recontextualization, nominalization, transitivity, frames, Nigeria, social actors, presuppositions

\section{Introduction}

\subsection{A Brief History of Nigeria's Socio-Political and Media Scene}

The application of CDA in the analysis of media representation of people, events and actions may contribute a lot in seeing the implicit albeit powerful impact of the media in the construction of our social realities. The media in Nigeria have been accused of not only misreporting events but of the subtle instigation of violent conflicts and crises due to sectional and sectarian interests (Kurawa, 2000; Usman \& Abba, 2000; Yusuf, 2002; Pate, 2003; Doki $\&$ Buhari, 2013). Since its independence in 1960, Nigeria has witnessed lots of conflicts that range from sectarian, political to ethnic crises. The cumulative consequences of these crises beside human toll are sharper mutual distrust, lack of unity and security which in turn impede national progress and development. At the level of human toll, Salawu (2010) estimates that the country has lost over three million lives and experienced incalculable psychological and material damages in the span of these crises. The media invariably play a significant role in this through constructing divisions, promoting warring identities and taking sides instead of setting agenda and themes of peace and reconciliation through objective and positive reportage of events.

Nigeria is the most populous black nation in the world. With about 150 million people of diverse ethnic and cultural differences, the country has seen a turbulent history of political, ethnic and religious crises since its independence in the year 1960. The Nigerian press, as many analysts have pointed out, has remained more of a liability than an asset to the existence of the country as a united entity. Usman and Abba (2000) particularly maintain that the Nigerian state has been arbitrarily constructed by the press and elite into two distinct, cultural, geographical, political, economic and religious antagonistic interests. The reportage of the press, as maintained earlier, has helped in this division of the country into two broad sides, i.e., Muslims versus Christians or the North versus the South or the Hausa and Fulani versus the south, and recursively in smaller dimensions. The southern part of Nigeria is largely Christian and is composed of two major tribes, the Igbo and the Yoruba; while the northern part is composed of largely Muslims with major tribes like the Hausa and Fulani and sizable number of minority tribes that are Christians. The southern part is mostly educated due to their early exposure to western education through missionary and colonial activities. While the Islamic north which has a tradition of Islamic scholarship dating back centuries was reluctant and wary in accepting education for fear that it might affect their religious orientation. This northern lack of interest would prove an undoing (to it) generally in the socio-political realities of the country. 


\subsection{The Jos Crises}

The two events reported in the Daily Sun (and which are our data here) happened in Jos. Jos is a city that is located in the central part of Nigeria. It is the capital of Plateau state. It is composed of different ethnic groups and two major religions, Islam and Christianity. Plateau state has (over the last decade) been the major site of ethnic and religious violence and conflicts in Nigeria. There have been recurrent crises all over in the state, both in the rural and urban areas. Higazi (2011) maintains that there are episodes of mass killings and destruction that have occurred in Jos in 2001, 2002, 2008 and 2010. The newspaper coverage of the crises, as outlined earlier, verges also on sectional and sectarian interests. Newspapers that are based in the Christian part of Nigeria defend the interest of people that share their faith and this is similar to newspapers owned by the Muslims. The preponderance of Nigerian newspapers in the southern part of Nigeria makes the views of those they favor by dints of faith or other considerations more heard and nuanced. This research paper will look at two news coverages from the same newspaper that report on some violent occurrences in Jos and environs involving two constructed divisions. The analysis is just an attempt to provide an empirical sample or model of the form of sometimes skewed reportage that abounds in the Nigerian media scene and that may have been contributing in deepening distrust and conflicts.

\subsection{The Daily Sun Newspaper}

The Daily Sun is the newspaper of our analysis. Dr. Uzor Kalu is the chairman of the Daily Sun, a Nigerian daily print newspaper founded and published in Ikeja, Lagos, Nigeria. The newspaper boasts of a daily circulation of about 130,000 copies as of 2011, and 135,000 for weekend titles, with an average of $80 \%$ sales. The Daily Sun is the highest selling newspaper in Nigeria. The paper was incorporated on March 29, 2001, and began production as a weekly on January 18,2003, and as a daily on June 16, 2003. The paper is an English newspaper outfit which offers a similar format to the popular Sun newspaper in the UK. The company has a head office in Lagos with six regional offices and about 42 distribution outlets across the country. This clearly shows how the newspaper is well distributed and well channeled to all parts of the country. In their mission statement obtained from their website, they maintain that their objective is to "practice journalism in the classical tradition of presenting the news and features in an exciting style, with impact, objectivity and appeal that generate returns to all stakeholders: the society, the investors and the practitioners" and their vision is to be a "dominant media content provider and entertainment company in Nigeria and Africa through the pursuit of excellence in delivering innovative and quality media and entertainment products". This research article aims to test this notion of objectivity and the classic tradition of journalism that it eloquently espouses to here.

\section{Review of Literature about Press Reportage of Conflicts in Nigeria}

This review would look at the analysis of newspaper reportage of conflicts and crises in Nigeria in the last six years and see how this paper will be different from the ones here. Doki and Buhari (2013) use Sobowole's (1983) content analysis format to present samples and evidences from the Nigerian press that are in violation of media laws and ethics. The result of the analysis indicates that the press in Nigeria instigates conflict through biased reporting, deliberate misrepresentation and partisanship. These actions, according to Doki and Buhari (2013), are as a result of ethnicity, religious differences and the need to settle political scores. Tobechukwu (2007) also uses content analysis to evaluate the press coverage of political crises and conflicts during President Obasanjo's regime. The results of this research shows that the Nigerian press has behaved more as active players in political crises and conflicts than as impartial judges.

In the application of CDA, Musa (2011) studies the reportage of events in two newspapers, THISDAY and Daily Trust, during the November 2008 religious crises in Jos. He does a comparative critical discourse analysis and arrives at the fact that the newspapers are regionally, ethnically and religiously aligned in their reports. He feels that the papers are constrained by factors like ownership, staffing, audience perception and location. He maintains also that the newspapers stoke existing problems through inflammatory and partisan representation of issues. Eti (2012), on his part, analyses the pattern of reporting the 2006 kidnapping of four expatriate oil workers in Delta state by using framing theory. He concludes that the Nigerian Press is "episodic" in the reportage of events rather than analytical. He submits that the media need to reverse direct description of events and invest in analyzing historical causes of events.

What is quite clear from these research papers is their preponderance on the fact that the Nigerian press is not objective in its reportage. However, this lack of objectivity could be much more discerned if close textual and contextual analysis is adopted. In this paper, I intend to use Van Dijk's (1988) discourse analytical research model with views from Fairclough (1995) and Van Leeuwen (2008) to offer a close textual analysis of the two news reports. I would also closely analyze the Nigeria's news production and consumption context as theorized by Van Dijk (1988). Hopefully, this combination may evince deeper insights into the concept of bias within the 
Nigerian press and also throw more light on the ways the media construct our social realities.

\section{Theoretical Framework}

Van Dijk's (1988) Discourse Analytical Approach is an interdisciplinary model that systematically analyzes media texts and talk textually and contextually. This approach views media discourse as an institutional practice involving news production and news reception. It is not enough to analyze media texts and show textual biases without looking at the wider socio-economic and cultural factors that may have influenced a particular form of news construction. Likewise, it is equally important to also look at the factors (textually and cognitively) that may have influenced aspect of reception which is the final target of any media text or talk. Essentially, the textual aspect of the analysis would look at the various levels of representation, that is, from the micro to the macro while the contextual component would "analyze the cognitive and social factors, conditions, constraints, or consequences of such textual structures and, indirectly their economic, cultural and historical embedding" (Van Dijk, 1988, p. 176).

This approach would all be used within the purview of the theoretical construct of Critical Discourse Analysis because of its concern with formulating an analysis of public discourse aimed at getting to the ideology coded implicitly behind outward propositions (Fowler, 1991). Hodge, Kress and Fowler (1979) define ideology as sets of ideas involved in the organization of experience and making sense of the world. The world abounds with ideologies of the powerful elements of the society due to their social positions and access to discourse. These ideologies pass off or are made to be the commonsense or the way things are naturally and inevitably. Though social theory has recognized the arbitrariness of ideology as Fairclough (1995) points out but it is put in abstract ways without analysis of close specific textual constructions. So, Fairclough (1995, p. 54) proposes that we combine insights of social theory "with traditions of close textual analysis which have developed in linguistics and language studies to make them operational, practically usable in analysis of specific cases". He further maintains that "connections between the use of language and the exercise of power are often not clear to people, yet appear on closer examination to be vitally important to the workings of power". Critical Discourse Analysis, as such, has come to remedy the theoretical insufficiency of social theory through close linguistic analysis of the nexus of its investigation.

Our concern in this paper is the analysis of newspaper reports which are discourse of a sort. News reports deal with representation of people and events in the scheme of things. This representation involves a lot of linguistic choices to be considered about how realities should (or be made to) appear. Though journalists hardly witness events, their work is based on other mediated discourses and perspectives from which they create a model of presentation for their audience, conforming to their own values. Right from choosing what constitutes news to choices of where to report and macro structural processes of news summation, there are choices to be made which may not be purely value-free. By defining and labeling phenomena, words and images frame the terms in which we think about these and may, in turn, influence decision-making and attitudes.

The construction of realities or models of reality is based on linguistic and schematic choices. A particular event can be referred to either as a revolution or rebellion, or a person either as a terrorist or a freedom fighter by different people because of essentially ideological differences. In essence, "whether the newspaper selects "terrorist" or "freedom fighter" to denote the same person is not so much a question of semantics as an indirect expression of implied but associated values incorporated in shared-word meanings" (Van Dijk, 1988, p. 81).Our choice of referential terminology here as such may be more about the nature of our opinion regarding those issues than what they truly are, or stand for. Furthermore, because people and events have multiple identities and classifications, it is also then a question of choice or opinion or of context to background or foreground a particular identity. A person can be a parent, a Muslim, an animal right activist, a teacher, etc. Thus whichever term is chosen to be used here is about how we want the world to look at that person in the context and frame it is used. We would see how such categorization has helped a great deal in drawing up two distinct frames in the two news reports under analysis.

In the aspect of clausal constructions, Simpson (1993) shows how the use of syntactical representations like passives, ergatives and nominalizations can overly foreground or suppress certain realities based on ideological leaning. There are choices to be made of how we want an issue to be encoded. We may decide to make it be an action with Agency, i.e., "John killed Ali", or an event "Ali died" or a state "Ali is dead". All the three can refer to the same situation yet with different levels of semantic dimensions. We can also decide to use either a passive or active voice, or use an ergative sentence depending on how we want our information to be read, understood and believed. Generally choices of lexical and clausal items in the press may lead to framing and as rightly observed by Fairclough (1989, p. 54)

the effects of media power are cumulative, working through the repetition of particular ways of handling 
an agency, particular ways of positioning the reader and so forth. Thus through the way it positions readers, for instance, media discourse is able to exercise a pervasive and powerful influence in social reproduction because of the very scale of the modern mass media and the extremely high level of exposure of whole populations to a relatively homogenous output.

At the global level of textual representation, there are also choices to be made in the press that may indicate ideological subjectivity in the treatment of people and events. There are choices of voices to be represented and their hierarchization which may influence news reception. Some voices are marginalized and some are foregrounded or taken up as the reporter's (Fairclough, 1995). There are also intertexual strategies, semiotic, and graphological devices that may all impact on the nature of news comprehension and presentation.

\section{Method}

As I said earlier, this research paper would attempt to analyze two newspaper reports by the Daily Sun as carried in these links: http://www.nigerianbestforum.com/index.php?topic $=132804.0 \quad$ and http://iveofofo.com/5675/massacre-family-of-8-wiped-out-in-jos/. These two stories appeared in both the print and online versions. These two stories follow each other within a gap of six days. The first news report pertains to the attack of the Muslims (men, women and children) on "Sallah" day as they were going to offer prayer to celebrate the end of the one month fasting period of "Ramadhan" in the Islamic Calendar. According to the National Youth Council of the JIBWIS "the Christian attackers used all sorts of weapons against the innocent Muslim worshippers and killed very many Muslims and burnt their flesh. Over 200 cars, hundreds of motorcycles and other valuables were destroyed, burnt and stolen". Six days after this attack, another one followed with the Muslims going to a village to attack households as reported by many news media in the country. In the second news report, a whole family is said to be killed. The former report appears not to have been thoroughly covered and reported by the press as the latter. This is the immediate context of the two incidents for us to have a clear picture of the situations involved in the reportage and their immediate temporal and causal contexts.

I intend to use models of discursive analysis developed by Van Dijk (1988) and insights from the works of Fairclough (1995) and Van Leeuwen (2008) as said earlier. I would analyze my data from three distinct levels of analysis, i.e., lexical, clausal, and rhetorical/schematic. We would begin from the lexical as our linguistic analysis of news text should move from the small scale (micro), through to clausal and onto larger-scale analysis of the organization of meaning as a whole (Richardson, 2007). I would pay more attention to the analysis of headlines and leads in the lexical and clausal analysis due to their importance in capturing the macro-propositions of the news, and at the schematic, look at the global level of representation and the hierarchization of news contents.

\section{Data Analysis}

\subsection{Lexical}

Words generally convey the imprint of society (Richardson, 2007), and in this our case it carries the imprint of the opinion and evaluation of the press. In this analysis, we would see how the actors involved are referred and named. As earlier pointed out, people generally have different categorizations and that if certain categorizations are chosen, this may involve exclusion of other categories for reasons that may be ideological. As Fairclough (1995, p. 114) maintains, "there are always alternative ways of wording (any aspect of) a social practice and that such alternative wordings and categorizations often realize different discourses" In this news reports we have two different victims of violence. We will look at how both victims are represented and categorized, and also how their attackers are. These are the two reports with their headlines and leads:

\section{Headline: Sallah celebration: 10 killed, many injured in Jos}

Lead: Sallah celebration by the Izala Muslim group on Monday turned sour as clash between the group and some youths led to the death of no fewer than 10 people while many were injured. The Izala members, who had gathered at the Rukuba Road praying ground for the end of Ramadan fast, were held hostage for hours by the youths from the area who had insisted that they would not be allowed to pass through their area back to town. A fight erupted between the two groups after efforts, which lasted for hours, by the security men to pacify the youths failed.

\section{Headlines: Massacre: Family of 8 wiped out in Jos}

Dad, Mum, 4-month-old among those killed by gunmen in midnight attack

Soldiers get shoot-on-sight order

Lead: Fulani herdsmen were on the rampage again yesterday, as another family of eight was massacred in 
Heipang, near Jos, the Plateau State capital. This time, Mr. Chollom Gyang, his wife, Hannatu and six children, including a four-month old baby fell victims.

In the first report, the victims are categorized as a group, i.e., "Izala Muslim group", "the group", "Izala members". In his categorization of social actors, Van Leeuwen (2008) maintains that social actors can be "individualized" or "assimilated". "Individualization" occurs when actors are treated as individuals, and they are "assimilated" when they are thought of as groups. He maintains further that great value is placed on individuality in many spheres of life. In fact, in Middle-class oriented newspapers, ordinary people are assimilated while elite persons are individualized. In this case, we see such an assimilation of individuals into a group as probably a strategy to deemphasize the emotional impact of their victimization. Another significant point here is about how the victims are treated as mass in the headline. They are chunked as "ten". Van Leeuwen (2008) calls such referential strategy, "aggregation", that's, to quantify people as just statistics. In such collectivization as group and statistics, emotional human attachment from readers may be a bit remote than if treated otherwise. On the other hand, the victims of the report on the family attack which happens as a reprisal are obviously "individualized". Not only are the victims clearly identified, but they are constructed into a family unit and contextualized in a discourse of violence as the victims. They are mentioned as family of eight: dad, mum and eight month old baby in the headline. In the lead, their names are also mentioned. "Dad, mum, a baby and children" are a naming strategy that is sure to evoke more sentiment than say an aggregation like eight killed at home. All this humanization helps in drawing sympathy and attention. Bell $(1991$, pp. 19, 158) observes that such personalization is "more newsworthy than a concept, a process, the generalized or the mass". In fact there is a deliberate reportorial distance in the first report where the victims are classified as group but this distance appears to be abridged with the second victims. One reality which clearly shows that a choice of classification or discursive grouping is ideological is that the group in the first report is not given this familial attribute even though families are usually involved in this religious occasion.

Moreover, while the attackers in the first report are assimilated, the attackers in the second report are clearly identified by their ethnic affiliation. Those who attacked the Muslim worshippers are called "youths from the area" and "some youths". This involves what Van Leeuwen (2008, p. 39) calls "indetermination". This (he states) "occurs when social actors are represented as unspecified, anonymous individuals or groups". "Indetermination" he further explains is realized by indefinite pronouns like "somebody, someone, some, some people". "Determination", on the other hand, occurs when the identity of social actors is specified as we have seen in the attacks on family. The attackers of the Christian family though not individually named, are identified by their ethnic affiliation and vocation, "Fulani herdsmen".

The words used to represent the actions are not weighed emotionally similar also. While the attack on the Muslims is "killed", the attack on the family is "massacred" and "wiped out". "Massacred" or "wiped out" is much more emotionally and connotatively nuanced than "killed". Moreover, the lexical load of negativity is more invested with the attack in the second report than the first. In the second report we have such lexical items in the lead and headline like: massacre, wiped out, gunmen, midnight attack, rampage, killed, massacred and victims. In the other report we have: killed, injured, hostages, death and fight. It is instructive to understand that the second report is terser than the first in the lead yet more loaded with negative evaluations.

\subsection{Clausal}

At the clausal level, we would try to view representation at the syntactic perspective including the grammatical transformations that may have occurred. The transitivity system will be used as the analytical tool. Simpson (1993, p. 88) perceives transitivity as the study of how meaning is represented in a clause. He further explains that it shows how speakers "encode in language their mental picture of reality and how they account for their experience of the world around them". Generally, transitivity involves processes, participants and circumstances. Processes are expressed by the verb phrases, participants by the noun phrases and circumstances by adverbial and prepositional phrases. similarly Van Dijk (1988, p. 177) also states "that syntactic structures may also express underlying ideological positions, for instance, by using possessive constructions and deleting agents from typical subject positions to dissimulate the negative actions of elite or powerful groups". Below is the first sentence of the lead in the first report:

"Sallah celebration by the Izala Muslim group on Monday turned sour as clash between the group and some youths led to the death of no fewer than 10 people while many were injured."

We have the "Sallah celebration by the Izala Muslim group on Monday" appearing as the Agent instead of the Affected participant and "turned" as the Process and "sour", the Attribute. In this construction, we have an "analytical causative". Downing and Locke (2006, p. 134) defines an analytical causative as a combination with verbs like "make" and "turn" "where an Agent brings about a change of state in the Affected participant. The 
resulting state is expressed by an Attribute." In this construction the Agent is deleted. Thus, it essentially means that the "Sallah celebration" turns itself sour. "Sallah celebration" is an abstraction and may not be able to initiate itself as it is neither a controlling Agent nor a Force but an Affected participant. A construction like: Berom Youths turned Sallah Celebration sour could provide the right controlling Agent using the ethnic affiliation of the attackers as provided in the other report. This could be similar in syntactical construction with the example of an analytical causative provided by Downing and Locke (2006, p. 134), "The heat (has) turned the milk sour".

In the adverbial clause, we have an interesting transformation in the way the whole crisis is described. The crisis is transformed into a nominalization, "clash" as in "as clash between the group and some youths led to the death of no fewer than 10 people while many were injured". "Clash between the group" is a nominalization which has stilled a clausal process and stinted information in the case. According to Toolan, (2001) a nominalization is a transformation of a clausal process into a noun phrase, thus treating the entire process as an established "thing"-which can then serve as a participant in another more inspectable process. It essentially freezes a process. Similarly, Downing and Locke (2006) see it as a grammatical metaphor that distances us from events, raising the representation of a situation from the iconic to a high level of abstraction. Throughout the news reports, the overall crisis is described with about seven nominalizations, i.e., clash (three times), crisis (two times) and fight (two):

(1) ... as clash between the group and some youths led to the death of no fewer than 10 people while many were injured.

(2) A fight erupted between the two groups after efforts, which lasted for hours, by the security men to pacify the youths failed.

(3) Daily Sun learnt that the fight was a fallout from the December 24, 2010 bomb blast in the area, ...

(4) Some of the residents confirmed that at least 10 people died in the clash but they could not say if more people died in the

(5) ... the crisis spread to Abattoir and GadaBiu area of Jos where more dead bodies were picked.

(6) The clash paralyzed commercial and social activities in Jos throughout Monday, ...

(7) Yeljab said government had directed the commissioner of health to make available enough drugs to hospitals where victims of the crisis were being treated.

We see clearly how agency and responsibility are mystified. All the nominalizations used to describe the situation have clearly not been explicit in trying to establish who the aggressor is other than to show mutual responsibility in the crisis. One other aspect of the nominalizations is the use of processes like "erupted" in 2, "spread" in 5 and "paralyzed" in 6. In "erupted" we see the situation as just being spontaneous by itself in the form of a geological phenomenon like volcanoes as they erupt. In speaking about agency, Downing and Locke (2006) differentiate between animate and inanimate agency and classify the word "erupt" as occurring within the realm of Force with energy or power that cannot be intentional and that can instigate a process but not control it especially in natural geological and psychological states like volcanoes, earthquakes, anxieties etc. Likewise in "spread" and "paralyzed" we see "crisis" and "clash" reified as if they spread and create a state of paralysis on their own without any human agency. What we have in all of these cases is an effort to avoid mentioning human agency that may indict a favored people in the overall crisis. This general obfuscation of causality appears not to be used in the other report shown below:

Fulani herdsmen were on the rampage again yesterday, as another family of eight was massacred in Heipang, near Jos, the Plateau State capital. This time, Mr. Chollom Gyang, his wife, Hannatu and six children, including a four-month old baby fell victims.

This lead clearly shows an entirely different form of reporting. In the report on the attack of the Muslims, we see both a linguistic and spatial distance in reporting the issues. But in this report we see this distance totally abridged. We see the name "Fulani herdsmen" used as Agents in "rampage" and associated with "massacre". "Rampage" is also a nominalization which shows frenzied violence associated with the attackers. In the first two paragraphs of the news report alone, the Fulani are mentioned three times as the assailants and those responsible for the death of the family members and previous attacks. In this case also, the victims are clearly stated with proper nouns, i.e., $\mathrm{Mr}$ Chollom Gyang, his wife, Hannatu and six children, including a four-month old baby fell victims and their is also a clear naming of their community "Heipang, near Jos" all these help in creating a sharper frame in the mind of the reader. In the other news, the victims are simply represented by a number and even then there is no any clear indication that the casualty figure is all Muslims. 


\subsection{Rhetorical and Schematic}

Van Dijk (1988, p. 83) sees the aspect of rhetoric as dealing with implicit persuasion whose perlocutionary effect is to get people to accept what you transmit to them. This involves "the formulations of meanings in such a way that they are not merely understood but also accepted as the truth or at least a possible truth". In this case we will look at the persuasive strategies involved in both news items to make their propositions credible and also to make their ideological interest sustained. We would look at how choices of whose voices to represent and what issues to be recalled have contributed in the overall rhetorical make-up of the stories This is because the various voices represented in news are hardly given equal weight, space and emphasis.

\subsubsection{Text Size, Headlines and the Use of Images}

First, in terms of size, while the report on the Muslims is 555 words, the report on the attacks of the Christian family is 1231 even though the cumulative loss of lives and property is far higher with the former than with the latter report. The size here clearly indicates the news report that is given much more prominence in terms of featured voices and thorough coverage. Secondly, the fonts used in reporting the headline of the attack on family is bolder and much more emphatic and is set on the background of a gory picture of the family slain. The use of images gives sharper impact in episodic memory and help to galvanize deeper emotion especially where the concept of a victimized family is used in the report. The headline used in the report on the family is segmented into three; the main headline and two sub headlines. Apart from the emotive semantic influence of the headline explained in the clausal and lexical chapters above, headlines also perform rhetorical functions of attracting the reader (Bell, 1991; Richardson, 1997).This rhetorical function is more invested in the three-tier headline than in the other headline.

\subsubsection{Presuppositions and Recall of Events}

According to Fairclough (1995) presuppositions "are what French discourse analysts call "preconstructed" elements in a text, elements which have been constructed elsewhere in other texts". In our analysis here, there are two important iterative presuppositions, i.e., "again" and "another" in "Fulani are on the rampage again as another family of eight was massacred in Heipang". These presuppositions help in building an intertexual chain of events that helps in strengthening a model or frame in the minds of news consumers as "updating presupposes previous models about a situation while understanding also requires the activation and application of frames and scripts" (Van Dijk, 1988, p. 121). Immediately following the lead, there is a clausal recall of similar event, that is "Just a week ago, eight members of a family were murdered by Fulani herdsmen". This recall of similar event is also an update of the frame and an expansion of the presupposition. This recall of events all helps in the buildup of a negative image of the assailants in this news report. The concluding paragraph of the news recalls yet the event on the attack of the Muslims. But interestingly, the attack on the Christian family has not been made to be a form of reprisal for the Sallah attack (which has preceded it), instead we have an implicit indictment of the Muslims as associated with violence. This is done through a clausal construction that yet again recontextualizes and foregrounds the Muslims in a discourse of violence, "the relative peace in the state suffered a severe blow on Monday, when youth groups clashed along Rukuba Road during the Eid El Fitr prayers by the Izala Islamic sect". Rather than placing the Muslims as victims, through this construction, they are shown to be as if they are the initiators of the violence they are victims of. In essence, "the relative peace in the state suffered a blow" as a result of the activities of the Izala Islamic Sect.

However, the attack on the Muslims does not have any strategies for a recall in their support even though there has been a series of attacks on them by the Christians in the same state (Higazi, 2011). Far from that the only recall here is to indict the victim. The attack on them is seen as a "fallout" ofa bomb blast that took place during a particular Christmas celebration: "Daily Sun learnt that the fight was a fallout from the December 24, 2010 bomb blast in the area, during which at least 30 people died thus disrupting the Christmas celebration". In this there is an implicit justification on the attack on the Muslims through the use of the word "fallout" which gives the notion of a justified consequence. Van Leeuwen (2008) would see this as a form of rationalization. This can be put in a single proposition, i.e., even if the attacks on the Muslims take place, it is because of a similar attack on the Christians in the last Christmas. In essence while intertexual resources are used to recall events in other to indict the attacker of the Christian family, it is used in the Muslim report to indict the victim and justify his misfortune.

\subsubsection{Verbal Reactions}

In the report on the attack on the Christian family, there are about six verbal reactions from important people in the society. In fact, immediately after the lead, there is the verbal reaction of the chairman of the BarikinLadi local government council, Mr. Emmanuel Dachollom. In his reaction, we see the decrying of the situation 
strongly. Coming from him as an important authority, this lends credence to the journalistic evaluation of the situation. Other commentators include Mr. F. Gyang, a member of the state legislature, Mr. Francis Jamang, National President of the Berom Youth Movement, the commissioner of Information, Mr. Abraham Yiljaf and Captain Charles Ekeocha, the army spokesman. All the commentaries are critical of the attack. In quoting them, the reporter here tries to give their names and position in the society all in a bid to probably give the impression of the weight of their opinion. The Hausa-Fulani Muslims in the commentaries have variously been referred to as "terrorists", "aggressors", and "fundamentalists"

On the other hand, the first two people to be quoted in the attack on the Muslims are anonymized with such terms as "some of the people who spoke to Daily Sun" and "some of the residents". These are the two first commentators about the situation placed in prominent hierarchy in the news and both try to give justification of the attack and downplay the casualty figure. Other comments include that of the army spokesman, who speaks more on the deployment of security and the Commissioner who decries the situation and simply calls it "regrettable". Another commentary is that of Ustaz Ahmad Muhammad who is the secretary of the Jama'atul Nasril Islam and whose commentary is shown as being uncertain about the number of deaths. What is of importance in our analysis here is the positioning of the commentaries and the comments which all have bearing on the overall macroproposition conveyed by the reports.

\subsubsection{Correspondent Eye Witness Testimony}

In the attack on the Christian family, we see that the correspondent has visited the victims and "observed" what has happened. S/he has seen the casualties and assessed the situation. This firsthand information from the journalist has truth value and can help tremendously in enhancing the credibility of the news report. The testimony here is by "expert authority" (Van Leeuwen, 2008) in the person of a journalist who has the power to see and report events. Besides that, it shows the concern of the paper with this particular casualty as this is not extended to the Muslim victims of the other report who are perhaps reported with some level of distance and detachment.

\section{News Production}

Generally news production involves structural adjustments, news values and cognitive constraints (Van Dijk, 1988). However in all of these cases ideological issues may be involved. The resort to choose which wire report to adopt or how to summarize a news item or which issue to be covered, or where it should be placed all may relate to the newspaper's ideological policy (remotely or directly). In our case, we have seen how the report on the attack of the family bridges distance between the event and their report by making their correspondent visit the scene to observe what happens, but in the case of the other attack there is a clear distance. This distance may be ideological. We have also seen how semiotic resources are used to enhance the factuality of the report on the attack of family by presenting a front-page gory picture of the slain victims. All these choices represent a conscious attempt to produce the news as it appears. However, what is of more concern to us in this report is the tendency to produce news items that are biased against the Muslims and which place them as perpetual troublemakers or fanatics (Kurawa, 2000) in the Nigerian news media. This would mean looking at the wider socio-cultural and political factors that may have contributed to this attitude. We argue that there are essentially four reasons for this position.

\subsection{Politics}

Generally, Northern politicians have dominated the political scene for long and their southern more educated counterparts are not happy with this and they resort to media campaign to discredit the Muslims chiefly as a tactic of political displacement. The owner of the Sun newspaper for example was once a presidential aspirant. Tobechukwu (2007) provides example of how the then speaker of the House of Assembly, Salisu Buhari, was impeached over certificate forgery, what the press then tagged "Buharigate", by the vociferous demands of the Southern Nigerian press, but they softened on Mr. Bola Tinubu, a southerner, who committed the same offense and hence was left intact in his position as Governor of Lagos state. He further argues that Nigerian newspapers are ethnicized and personalized instead of being broadly issues-based in their reportage. It is also this political issue that makes the southern press adopt a pro middle-belt stance in news items so that that this could politically weaken the perceived hegemony of the Hausa and Fulani political elite in the North.

\subsection{Economics}

At the level of economics, the north has always agitated for the establishment of an Islamic "Sharia" system. The "Sharia" is a term literally meaning "the way or the road", and it entails the establishment of an Islamic legal system. The implementation of the Sharia in the vast northern states will affect the businesses of people in the 
breweries and hospitality industries mostly owned by the Southern Nigerian Christians because the Sharia will ban the drinking of alcohol and the like. In addition, English newspapers are elitist media due to the requirement of literacy and the understanding of English (Olayiwola, 1991). This means that the consumers are more likely to be found in Christian dominated places. Kurawa (2000, p. 85) explains further:

It is an obvious fact that most of the owners of Nigerian newspapers are Christians and secularists. Similarly most advertisers in the media are Christians or even brewers who may lose their businesses with the implementation of Shari'ah Criminal Code. Further the majority of readers of Nigerian newspapers are also Christians and other representatives of Western Christian Civilization.

So, there is the consideration of the readership demographics and their worldviews and beliefs which have to be represented in news coverages.

\subsection{Religious Differences}

Closely related to the point about the economics of the Sharia is the aspect of religion in its essence. The papers are not only situated in the southern part of Nigeria but the journalists are mostly Christians in faith and they see the news room as an extension of the area of religious conflict between Islam and Christianity. Kurawa (2000) maintains that the southern papers even try to tag any person that agitates for Islamic rights as a fanatic or troublemaker. Usman and Abba (2000) particularly criticize the reportage of events in Kano (northern Nigeria) by The News magazine for being highly inflammatory and inciting against the Muslims of Kano. Apart from this, the papers are also torn along tribal lines (Tobechukwu, 2007; Olayiwola, 1991)

\subsection{Western Media Influence}

The negative perception of Islam and Muslims in the western media also influences our local journalists in adopting similar perception. Arowolo (2010) talks a great deal about the pervasive western influence generally on African values. This influence makes us sometimes see the west as superior in thoughts and perception. This perception is reflected especially in the notion of terrorism. Most of the crises that take place in Nigeria are not essentially viewed as terrorism unless if the perpetrators are Muslims. In our news report on the attack of the Christian family, we see how the Barikin Ladi Local Government Chairman categorically calls the attackers "terrorists". This may not be unconnected with the effect of western media perception of Muslims.

\section{News Comprehension}

According to Van Dijk (1988), news readers generally recall the macro structures of the news especially the headlines, and these, after sometimes, merge into general frames. Readers essentially update the old model of a news item with a fresher one. In the case of our news items here we have seen how both headlines are couched and the mechanisms of recall deployed in both and which among the two is much more nuanced. There are so many assumptions and presuppositions in news items that cue the readers' knowledge of issues and that is why it is considered "a tip of the iceberg" (Van Dijk, 1988), and the readers are expected to dig deeper cognitively and get the overall gist. Fountaine and McGregor $(2002$, p. 2) provides two perspectives of what it means to frame events and issues.

First the media can be said to frame events and issues the same way a photographer frames a photograph, choosing what aspects to highlight or draw attention to, and what part to leave out (Capella \& Jameson, 1997). Similarly, a media frame can be likened to the frame of a house, providing the structure around which everything else fits, and influencing the overall style of the construction (Tankard, 2001).

The construction of frames gives the press an opportunity to present their own model of social reality. In these two reports that we have here the whole stories could be different depending on the ideological perspective of the reporting press. The Muslim victims could be reported with a headline like this: Muslims attacked in Worship or Families killed while praying and the Christian family Eight killed at home or something like this. Such scripts and frames would certainly realize different reactions unlike otherwise. While essentially social reality remains fixed, perceptions as we can see here may differ. Readers' reaction is based on how reality is couched and dressed for their consumption. In our case in this paper given the news values of the media discussed in the production aspect, the "Northern Muslim" script is always played out and associated with violence irrespective of what the picture holds. Through the structural choices deployed in the news reports, both where the Muslims are the victims and where they are the assailants, the frame of violence is clearly shown. The way the news items are constructed, there is hardly any way that the Muslims would dodge the frame of violence associated with them. The building up of the script of family to represent the Christian victims on the one hand and the aggregation of the Muslims as number and group involved in violence on the other is meant to sustain and 
update predetermined frames. The macro-propositions that may be recallable in the first report is mutual killings involving a group of Muslims with others (unspecified or unknown), and in the second report, massacre committed by the Hausa-Fulani Muslims. All strategies to make these propositions credible and believable are taken, from the micro to the macro levels of the news presentation.

\section{Conclusion and Significance of Findings}

This analysis provided above may have clearly shown how bias is established systematically in the press. The use of Critical Discourse Analysis has helped in deconstructing the intricate manipulation and positioning of texts (in these two reports) in order to underscore an ideological viewpoint. It is not enough to claim the existence of bias without proving it systematically as is attempted here. Though the two news reports are from the same paper and reporting events from the same area and involving the same theme of violence, the reportage appears considerably skewed in favor of people probably preferred by the paper. The report on the Muslims appears generally to mitigate the gravity of the human toll in that event while in the second one it appears to foreground and overly magnify the incident through structural choices.

The theme of family is played out in that report while in the Muslim attack not only is the theme of "worshippers" or "families" on a solemn religious mission not highlighted but that the group is made into statistics and then involved in a theme of violence in both the reports. In the first report, they are involved in a fight where no aggressor is clearly identified, while in the second one they are clearly identified as the aggressors. In the aspect of reception, apart from the textual representation, the second report is more likely to be recalled and taken more seriously than the first due to the use of schematic, semiotic and graphological strategies deployed there far ahead of the first. With the frames constructed, events will continue to happen and will be placed in their framed pigeonholes and that social reality will continue to be a matter of opinion not objective facts.

By and large, the significance of this study is essentially twofold. First, it has perhaps indicated that textual analysis does not suffice to determine the subjectivity of a newspaper report. It has to be supplemented with analysis of the factors of news production and also the factors that may influence news reception. The analysis of texts would only show a superficial level of representation without demystifying the underlying reasons. Journalists do not exist in a vacuum; they are a construct of their own system and society. In this analysis, we have shown how the socio-cultural factors in the society may have influenced a particular news attitude, a form of coverage that reports certain people differently.

Secondly, it has also tried to show that reality can be represented in different forms and can realize different truths and reactions. People and events can be shown from different vantage positions. In this paper, we have seen how certain people are grouped en masse and reported with probably the aim of trivializing the emotional impact of their victimization, and we have also seen how others are reported with their individuality and familial features foregrounded for sentimental reasons. There are many choices of lexical, clausal and rhetorical resources that can be used to present our versions of reality taking our own ideological perspectives into them.

\section{References}

Arowolo, D. (2010). The Effects of Western Civilisation and Culture on Africa. Afro Asian Journal of Social Sciences, 1. Retrieved September 20, 2013, from http://www.onlineresearchjournals.com/aajoss/art/53.pdf

Bell, A. (1991). The Language of News Media. Oxford, UK: Blackwell.

Doki, A. M., \& Buhari, Y. (2013). Embracing Peace Journalism in Stopping Violence-Provoking News in Nigerian Media. Nigerian Journal of Religion and Society, 1, 20-35.

Downing, A., \& Locke, P. (2006). English Grammar: A University Course (2nd ed.). London: Routledge.

Eti, C. I. (2012). Deconstructing the Reporting of Hostage Taking in the Niger Delta. Global Media Journal African Edition, 6(1), 23-42.

Fairclough, N. (1989). Language and Power. London: Longman

Fairclough, N. (1995). Media Discourse. London: E. Arnold.

Fountaine, S., \& McGregor, S. (2002). Reconstructing gender for the 21st century: News media framing of political women in New Zealand. In M. R. Power (Ed.), Australia \& New Zealand Communication Association 23rd Annual Conference (pp. 1-7). Brisbane: ANZCA.

Fowler, R. (1991). Language in the news: Discourse and ideology in the press. London: Routledge.

Fowler, R., Hodge, B., \& Kress, G. (1979). Language and Control. London: Routledge and Kegan Paul.

Higazi, A. (2011). The Jos Crisis: A Recurrent Nigerian Tragedy. Friedrich-Ebert-Stiftung, 1, 1-32. 
Kaura, I. A. (n.d.). Publications. National Directorate of Education, JIBWIS. Retrieved October 13, 2013, from http://jibwisng.org/english\%20pages/English\%20Publications.php

Kurawa, I. A. (2000). Sharia and the Press in Nigeria: Islam versus Western Christian Civilization. Kano: Kurawa Holdings Limited.

Leeuwen, T. (2008). Discourse and Practice New Tools for Critical Discourse Analysis. Oxford: Oxford University Press.

Massacre-Family of 8 Wiped Out In Jos. (n.d.). Nigerian Celebrity News Online Magazine RSS. Retrieved September 29, 2013, from http://liveofofo.com/5675/massacre-family-of-8-wiped-out-in-jos/

Musa, A. (2011). The Role of Political, Socio-economic Factors and the Media in Nigeria's Inter-religious Conflict. Doctoral Thesis, University of Liverpool, $1,1$.

Nigerian Best Forum. (n.d.). SALLAH CELEBRATION: 10 KILLED, MANY INJURED IN JOS. Retrieved September 25, 2013, from http://www.nigerianbestforum.com/index.php?topic=132804.0

Olayiwola, R. O. (1991). Political Communications: Press and Politics in Nigeria's Second Republic. African Council for Communication Education, 5(2), 31-45.

Pate, U. (2003). Professionalism, Diversity Reporting and the Media in Nigeria. Presented at a departmental seminar organized by the Department of Mass Communication.

Richardson, J. E. (2007). Analysing Newspaper an Approach from Critical Discourse Analysis. New York: Palgrave .

Salawu, B. (2010). Ethno-religious Conflicts in Nigeria: Causal Analysis and Proposals for New Managment Strategies. European Journal of Social Sciences, 13(3), 345-353.

Simpson, P. (1993). Language, Ideology, and Point of View. London: Routledge. http://dx.doi.org/10.4324/9780203312612

Sobowole, I. (1983). Scientifi Journalism. Lagos: John West Publications Limited.

The Sun News About Us - The Sun News. (n.d.). The Sun News - Voice of The Nation. Retrieved October 20, 2013, from http://sunnewsonline.com/new/about-us/

Tobechukwu, E. N. (2007). The Nigerian Press Coverage of Political Conflicts in a Pluralistic Society. Global Media Journal African Edition, 1(1), 66-91.

Toolan, M. J. (1988). Narrative: A Critical Linguistic Introduction. London: Routledge.

Usman, Y. B., \& Abba, A. (2000). The Misrepresentation of Nigeria The Facts and The Figures. Zaria: Ceddert.

Van Dijk, T. A. (1988). News as Discourse. New Jersey: Lawrence Erlbaum.

Yusuf, B. (2002). Media Coverage of Ethnic and Religious Conflicts in Some Parts of Northern Nigeria. In A. Jika et al. (Eds.), Mass Media and National Development. Kano: Mubin Publishers.

\section{Appendix}

News reports used in the analysis

Massacre: Family of 8 wiped out in Jos

Dad, Mum, 4-month-old among those killed by gunmen in midnight attack

Soldiers get shoot-on-sight order

From ANDREW AJIJAH, Jos

Monday, September 05, 2011

Fulani herdsmen were on the rampage again yesterday, as another family of eight was massacred in Heipang, near Jos, the Plateau State capital. This time, Mr. ChollomGyang, his wife, Hannatu and six children, including a four-month old baby fell victims.

Just a week ago, eight members of a family were murdered by Fulani herdsmen. The Chairman of BarkinLadi Local Government area, Mr. Emmanuel Dachollom, had reported the incident to the Federal Government. He said that the attackers came from Mahangar, a Fulani community. According to him, if the federal authorities had acted on his alarm, the latest incident would have been averted. 
Our correspondent, who visited the house of the late Mr. Gyang, observed that some of the victims had deep machete cuts all over their bodies while others suffered gunshot injuries. Mr. Dachollom said: "We have made appeals to the Federal Government; we have told them that the people in the area (Mahangar) have lots of sophisticated weapons, but government has refused to do anything about it.

"I personally complained to a Federal Government delegation that came to investigate the killing last month, of eight members of another family, but our concerns and fears have been ignored." He said that the military Special Task Force (STF) recently searched a house in Mahangar and recovered sophisticated weapons, but that they did not have the will to search the whole community. Dachollom warned that unless the weapons in the area were mopped up, they would continue to constitute threats to the communities.

"Now, our people have been pushed to the wall. We have been appealing to them to be calm and not take the laws into their hands. We do not know for how long we can wait for government to protect us.

"If our youths go on the rampage, nobody should blame us; we have asked them to constitute themselves into vigilance groups to defend themselves against aggressors," he said.

Mr. Gyang Fulani, a member representing the area in the House of Assembly, said that the people could no longer trust government to protect them as it had failed them with the constant attacks. He regretted that the security personnel had not been able to fish out the attackers as no single arrest had been made, accusing the STF of lacking the will to stop the Jos crisis. "We said few years ago that terrorists were in the country but government didn't take us serious.

Now, it is glaring from the security challenges all over the country.

"The terrorists in Plateau are easy to fight because they are known, but government is complacent about confronting these fundamentalists. It is a ticking time bomb that will soon explode," Fulani said.

He challenged the people of his constituency to now rise up to the security threats and defend themselves against the aggressors at all cost.

"We will never calm the youths again; we will allow them rise up to protect their communities and their land from these unprovoked attacks. "We now know who the aggressors are. When police advised Izala sect leader, SaniJingir, not to go to Rukuba Road for the Sallah prayer, he refused and had now put the whole Jos into crisis," he stated.

Mr. Francis Jamang, National President, Berom Youth Movement, said the situation had reached a stage where they might be forced to take the laws into their hands if their attackers were not brought to book.

"The Berom people have now been pushed to the wall; no one should blame us for whatever action we take," he said.

Meanwhile, the state government has condemned the new wave of killings and tasked the communities to be at alert so as to defend themselves against aggressors. The Commissioner for Information, Mr. Abraham Yiljap, told newsmen that government was sad that violence had continued in spite of efforts to restore peace."No matter the number of military and police personnel, they are not enough to protect everyone. So, government is calling on community and religious leaders and politicians to enlighten their people to help themselves.

"Arrangements should be made to protect the people; let people take measures to safeguard lives and property in every community," he said. Yiljap, however, tasked the various community and ethnic groups to adopt dialogue, saying that dialogue still remained the best solution to the lingering crisis. Police Commissioner Emmanuel Ayeni, could not be reached for comments while the command's spokesman, Apev Jacob, could not comment on the development.

Capt. Charles Ekeocha, the STF's spokesman, in his reaction to the attacks, said that the STF had no business with the area. He explained that the task force withdrew its men after the communities in the area said they did not want them. He said: "The security of that area is not the concern of the STF; they have said that we are responsible for the attacks." In fact, officials from the Army headquarters came and investigated the claims of the communities and we are still awaiting the outcome of their findings.

"They have always accused our men of the attacks, so, I do not know who could have attacked them now that our men have been withdrawn." Reminded that the STF is in charge of security in the entire Plateau, Ekeocha agreed, but quickly added that soldiers were not in charge of that specific area as they had been accused of masterminding the attacks over time. 
"There was even a time they claimed to have picked military ID cards at the scene of such attacks. So, we are out of their area. I suggest you contact the police security team, Operation Rainbow," he said.

Meanwhile, angered by rampant shooting of its men, STF had mandated soldiers to shoot on sight, any one carrying or using arms on others.

"The STF is now mandated to use all the necessary force within its powers on anybody carrying and using arms or dangerous weapons on another person," its spokesman said. Capt Ekeocha, in a statement in Jos on Sunday, warned the youths against "testing the might of the soldiers," saying that whoever did that would be doing so at his or her peril. Ekeocha disclosed that three soldiers, shot by the youths, were lying critically ill in the hospital and regretted that they were gunned down by people they were supposed to protect.

According to him, "everywhere in the state is infested with weapons, with sporadic shots heard both day and night."

"The sporadic shooting by the Muslim and Christian youths, is also targeted at the soldiers," he regretted, and advised politicians, traditional rulers, religious leaders and parents to counsel their wards.

"The soldiers are no more prepared to turn the other cheek," he warned. Ekeocha, however, urged the people of the state to go about their normal activities as the STF and other security agencies were prepared to protect them.

The relative peace in the state suffered a severe blow on Monday, when youth groups clashed along Rukuba Road during the Eid-el Fitr prayers by the Izala Islamic sect. Several lives and property were lost during the fracas with many more injured while vehicles and shops were also burnt down.

Sallah celebration: 10 killed, many injured in Jos

From MARIAM ALESHINLOYE AGBOOLA and ANDREW AJIJA, Jos

Tuesday, August 30, 2011

Sallah celebration by the Izala Muslim group on Monday turned soured as clash between the group and some youths led to the death of no fewer than 10 people while many were injured.

The Izala members, who had gathered at the Rukuba Road praying ground for the end of Ramadan fast, were held hostage for hours by the youths from the area who had insisted that they would not be allowed to pass through their area back to town.

A fight erupted between the two groups after efforts, which lasted for hours, by the security men to pacify the youths failed.

Daily Sun learnt that the fight was a fallout from the December 24, 2010 bomb blast in the area, during which at least 30 people died thus disrupting the Christmas celebration.

Some of the people who spoke to Daily Sun disclosed that due to the failure by the government to address the situation squarely at that time, the aggrieved youths had also vowed to make the sallah celebration unpalatable for the Muslims this time around.

Some of the residents confirmed that at least 10 people died in the clash but they could not say if more people died in the hospital.

Efforts by to confirm the death toll from security agencies failed as the Police Public Relations Officer, ASP Jacob Apev, said he was in a meeting at the time Daily Sun called and would not be able to confirm anything until after the meeting.

Spokesman of the Special Task Force, Captain Charles Ekeocha, who declined to confirm number of those killed, told newsmen at the force headquarters in Jos, that members of the taskforce had been deployed to trouble zones, adding that security surveillance had been strengthened in the state.

However, Secretary of the Jamatul Nasri Islam, Ustaz Ahmed Muhammed told Daily Sun that a couple of people were killed, saying the association was still counting its causalities and would release the number later. "We have just buried some this afternoon," he said.

Chairman of the youth in Kabong area, Mr. Yusuf Kadiya, also told journalist at the NUJ press centre in Jos that nine of its members were killed and several others sustained injuries when, according to him, soldiers opened fire on them.

From information gathered by Daily Sun, the crisis spread to Abattoir and Gada Biu area of Jos where more dead 
bodies were picked.

The clash paralyzed commercial and social activities in Jos throughout Monday, especially around Kabong, GadabiulRukuba Road, Bukuru Park Round About, Bauchi Road, Nassarawa Gwom, part of Abattoir and Ahamdu Bello Way.

Reacting, Plateau State Commissioner for Information, Pastor Abraham Yeljab and the Special Adviser to the governor on Media, Pam Ayuba in a press briefing, described the incident as regrettable.

Yeljab said government had directed the commissioner of health to make available enough drugs to hospitals where victims of the crisis were been treated.

He confirmed that those injured were at the Evangel Hospital in Jos.

The information commissioner, who briefed journalists, called for calm, explaining that adequate security measures had been put in place.

He said government was meeting with top security chiefs in the state over the unfortunate incident.

\section{Copyrights}

Copyright for this article is retained by the author(s), with first publication rights granted to the journal.

This is an open-access article distributed under the terms and conditions of the Creative Commons Attribution license (http://creativecommons.org/licenses/by/3.0/). 